\title{
Ramayana In Java A Study Of Visual Art Style Transformation
}

Kusen

Keywords: reliefs; hinduism; java; arts; assimilation; acculturation; culture

\section{How to Cite:}

Kusen. (1990). Ramayana In Java A Study Of Visual Art Style Transformation. Berkala Arkeologi, 11(1), 1-12. https://doi.org/10.30883/jba.v11i1.547

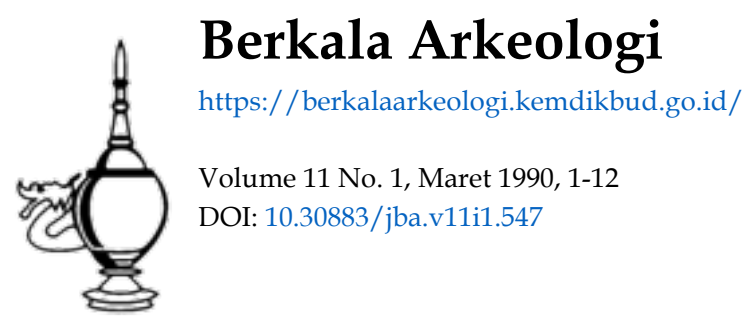




\title{
RAMAYANA IN JAVA A STUDY OF VISUAL ART STYLE TRANSFORMATION
}

\author{
oleh: \\ Kusen
}

\section{Introduction}

Ramayana, is the story of a noble character named Rama and his devoted wife Sita. This epic is attributed to an Indian poet, Walmiki. It may have been composed as early as the fourth century BC, while the work had probably attained its present form by the end of the second century AD (Finegan 1952: 152). At first it was only communicated orally or through literature, but then it was also communicated in visual art forms.

Along with Hinduism, the Ramayana spread from India to other countries. It reached and became popular in Indonesia, particularly in Java and Bali. That the Ramayana has been well-known in Java from a long time can be seen from the following facts. Firstly, the inscription of Canggal issued by King Sanjaya in 732 $A D$ says that the $K$ ing is as valiant as Sri Rama (Poerbatjaraka 1975: 34). Secondly, at Prambanan temple there is series of Ramayana reliefs depicted on its balustrades. This temple was inaugurated in $856 \mathrm{AD}$ (Casparis 1956: $280-311$ ).

A transformation of a story into a visual form is not a simple thing because there are many factors involved in this process. The major thing faced by an artist is how to get a model for the figure being made. From a general point of view there are two basic ways of transforming a story into a visual form. The first one is that the artist creates a figure based on his or her own imagination and interpretation of the character of a hero described in the story. The second one is that the artist just copies a previous form precisely or with modifications. 
In the case of the transformation of the Ramayana into a visual form, there are two major questions that must be answered i.e. how the Javanese artists created the figures, and what factors were involved in this process of creativity!

\section{The yisual art style transformation}

Before answering those questions, it is better to pay attention to the visual art style in Java. Based on previous studies (e.g. Holt 1967; Goedarjono 1981; Kusen 1985), it can be stated that there are three visual art styles of Ramayana in Java. The first one is the realistic or naturalistic style represented in the reliefs on the Prambanan temple (9th c. AD), the second style is the "semi decorative" style represented in the reliefs on the Panataran temple (14th c. AD) and the Mantingan mosque (16th c. AD0, and the last one is the decorative style represented in the Javanese wayang puppets.

To show the changing of the art style clearly, the description of the figures of Ramas in reliefs and wayang puppets will be served as examples.

In the Prambanan reliefs the figure of Rama is depicted in a realistic style. This means that the appearance of his figure is similar to that of the real human figure. The figures of Rama from Panataran and Mantingan are also depicted in a realistic style but he seems stiff or rigid; his face is depicted in threequarters, his body in three-quarters or frontal and when he stands his legs are depicted in profile. Because of his stiffness, he tends toward a decorative style which I call a "semi decorative" style. Unlike the Rama figure in reliefs, in wayang puppets his figure is depicted in a decorative style. His body and limbs are drawn thiriner and longer than the real human anatomy.

The costume and accessories worn by the Rama figure in reliefs and wayang puppets have changed from 
time to time. This also shows that there was a changing of style in visual art. It is, however, impossible to discuss all of the differences, so we only choose prabha (halo) as an example. Our data show that the prabha oniy appears in the Prambanan reliefs and in the wayang puppets type $A$ (there are two types of Rama figure in wayang; type A depicts Rama as a king, type B depicts Rama as both a prince and a warrior).

3. The Javanese artist's creativity and the factors involved in the process of creativity

Based on the description in section 2, it is clear that there was a visual art transformation in Java. Hoewever, it is not enough to only know this without searching for the factors which determined it.

To seek the determinants, we can start from Ernst Kris statement: "The study of art is a part of the study of communication. There is a sender, there are receivers and there is a message." (Kris 1953: 16). Here, the sender is the artist who sends his message by using the medium of art and the receivers are the people (also researchers) who receive the message.

In the case study of visual art of Ramayana, we can develop Ernst Kris' statement to build a model of approach:

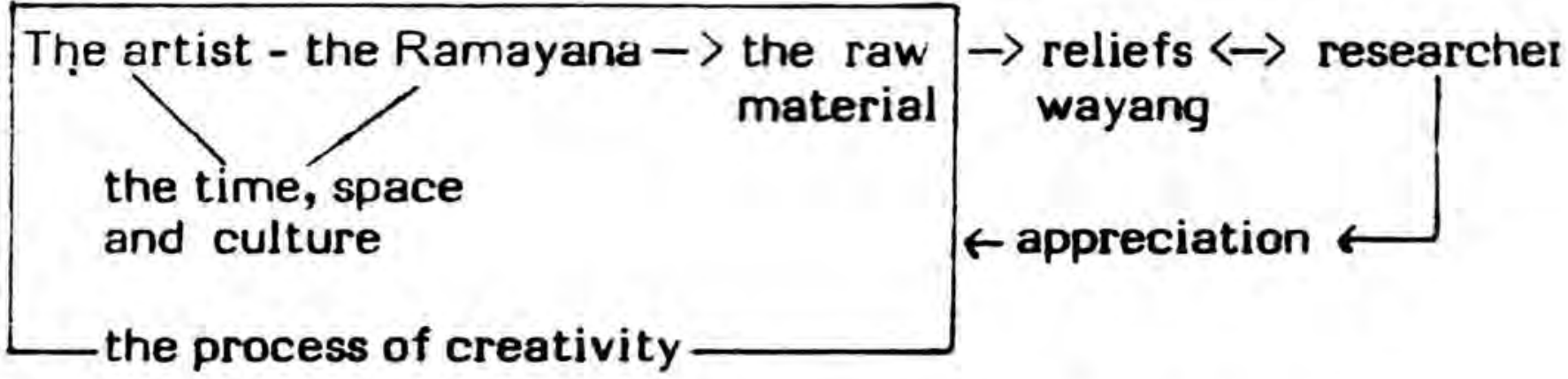

The explanation of this model is: When the artist transforms the Ramayana into visual forms (e.g. reliefs and wayang puppets), he must be influenced by the culture that exists in a certain place and time (where and when 
he iives) and he has to consider the raw material being used. So, if a researcher tries to appreciate the art created by the artist, he has to look for the factors that were involved in the process of creativity. The factors to be considered can be divided into two categories i.e. the external factors (the time, space, culture and raw material) and the internal factors (the artist's skill, taste, point of view, creativity etc.).

Based on this model of approach, we can explain the background of the visual art transformation as the following:

The prabha in Hindu and Buddhist iconography is a symbol of deity. So, its presence in the figure of Rama from Prambanan and the wayang type $A$ and its absence in the Rama figure from Panataran, Mantingan and the wayang type $B$ are not by accident, but must be done for a reason. It can be assumed that the reason is different perceptions about the status of Rama. Perhaps the artist of Prambanan believed that Rama, as an incarnation of Vishnu, had the same character as his Lord, so he must have a prabha. On the other hand, the artist of Panataran and Mantingan tended to see Rama as a warrior, so be has depicted the hero without a prabha. If this explanation can be accepted, it is clear that a cultural factor (in a certain time and place) has determined the result of the artist's creation words there is an interaction between the artist and external factors. But, how about the Rama type A which has a prabha and the Rama type $B$ which has not a prabha? In a wayang performance, the type $A$ is used when Rama acts as a king while type $B$ is used when he acts as a prince (a warrior). In Javanese tradiion (influenced by Hindu perception), a king is an incarnation of God, so it is not strange that Rama type $A$ has a prabha and the Rama type B has not.

We have already discussed the influence of cultural factors in the process of creativity. Now, we are going 
to discuss the influence of the raw material. Herbert Read has said that observation of the quality of material is the first stage of artistic creativity (Read, trans. by Soedarso 1971: 6). This means that before working, an artist has to observe the quality of the material being used. Each material has a specific character which needs different treatment. The differences between materials can lead the art produced towards different styles. This will be clear if we analyze the facts we have got.

The ornamentation of a wayang figure is made in more detail than that of a relief figure. It is assumed that this is caused by the different materials used. Leather is a pliable and strong material and it is easier to treat than stone. So it is easy to understand that a wayang figure looks more ornate than a relief.

A figure in a narrative relief never stands alone, it is always depicted in a group. Almost all figures in reliefs are depicted in the same way: their faces in three-quarters, their boies in three-quarters or frontal. All the figures of wayang puppets are free-standing figures and almost all of them are depicted like this: their faces in profile, their bodies in three-quarters and their legs in profile. Although they are depicted differently, reliefs and wayang puppets have the same function i.e. they are used as a medium of communication between the artist and the people.

From a communicative point of view, the appearance of relief figures have many advantages. The position and orientation of their faces (in three quarters) makes it possible for observers to imagine the relation between the figures in a scene. So the observers can interpret the story easily. The three-quarters face also gives a volume to the relief figure's appearance which is difficult to gain if the face is depicted in profile. The body, which is depicted inthree-quarters, also 
enables the artist to attach details (costume etc.) easily. These details may have iconographical values.

As free-standing figures that will be used as "actors"in a performance, each of the wayang puppets must have its special characteristic which makes it easy for the observers to identify who he or she is. The artist has chosen the faces of wayang puppets to depict these characteristics. So it can be seen that in wayang puppets there are "15 types of eyes, 13 types of noses and 11 types of mouths" (Soedarsono 1983: 415). Combining these various types of eyes, noses and mouths, an artist can easily create many figures which have their own character. This is difficult to do if the artist uses a realistic style, but it is easy to depict if the artist uses a decorative style.

\section{Conclusion}

The Ramayana is well-known in Java. The Javanese

The Ramayana is well-known in Java. The Javanese artist has transformed this story. into visual art forms e.g. in reliefs and in wayang puppets. There are three visual art styles of Ramayana in Java i.e. the realistic, "semi decorative" and decorative style. This shows that there was a visual art transformation in the past. It is assumed that this transformation was caused by certain factors which were involved in the process of the artist's creativity. These are internal factors (the artist's skill, taste, point of view, creativity etc.) and external factors (the time, space, culture and raw material). Based on our analysis, it seems that this assumption tends to be correct. However, to verify this hypothesis, further research on this topic must be continuously done. Whatever the result of future researches we can conclude that the Javanese artists had a high level of creativity. When transforming a story into a visual form they were not afraid to make modification or innovation. 


\section{KEPUTAKAAN}

Caspari s, J.G. de, 1956. Prasasti Indonesi a II. Bandung: Masa Baru.

Goedaryono. 1981. Ti njauan seni rupa wayang dari reli ef candi Jawa Timur ke bentuk wayang purwa. Dalam Darusuprapto, Pokok-pokok studi tentang wayang. Yogyakarta: Badrawada, Hlm. 20 - 23.

Holt, Clai re. 1967. Art in Indonesi a: conti nuities and change. Ithaca: Cornell Uni versi ty.

Finegan, J. 1952. The Archaeology of World Religi ons. Princeton: Pri nceton Uni versi ty.

Kats, J. Het. 1923. Javaansche Tonneel I: Wayang Poerwa. Weltrevreden: Commossi e voor de Volkslectuur.

Kempers, A.J. B. 1959. Anci ent Indonesi an Art. Massachussets: Harvard Uni versi ty.

Kusen. Kreati vi tas dan kemandi ri an seni man Jawa dalam mengolah pengaruh budaya asing. Studi kasus tentang gaya seni reli ef candi di Jawa antara abad IX - XV I Masehi. Yogyakarta: Proyek Peneli ti an dan Pengkaji an Kebudayaan Nusantara (Javanologi ).

Poerbatjaraka, R.M.Ng. Ramayana Jawakuno. Mi si , No. 1.

Poerbatjaraka, R.M.Ng. Ramayana Jawakuno. Mi si , III, No. 1 1965 hlm. 1-10.

Poerbatjaraka, R.M.Ng. 1952. Ri wayat Indonesi a I. Djakarta: Jajasan Pembangunan.

Read, H. 1971. The Meaning of Art. trans. Soedarsono, Pengerti an Seni I. Yogyakarta: STSRI, "ASRI".

Soedarsono. 1983. Wayang Wong in the Yogyakarta Kraton. Di ssertasi, Uni versi ty of Mi chi gan. 


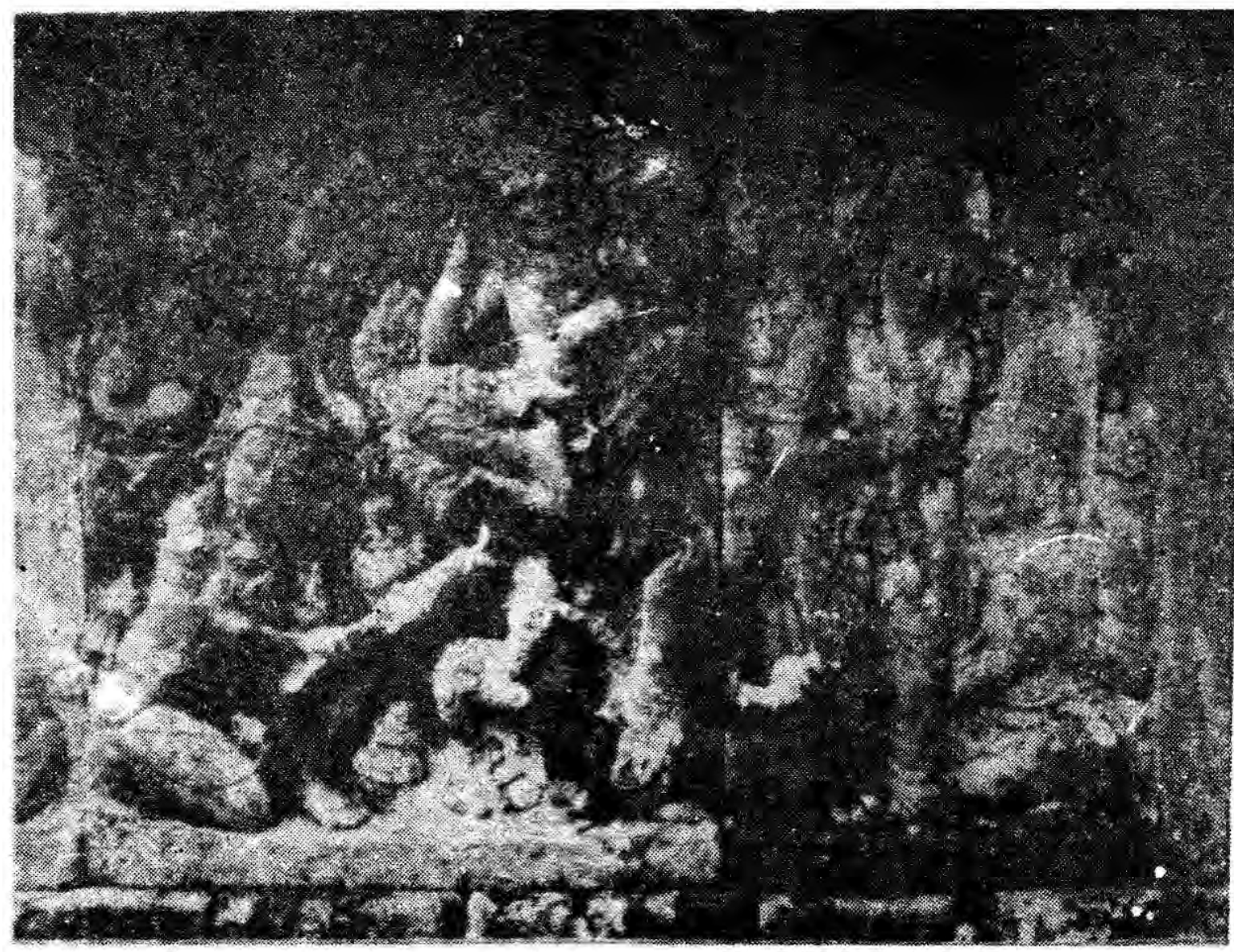

1. Prambanan relief. Rama 


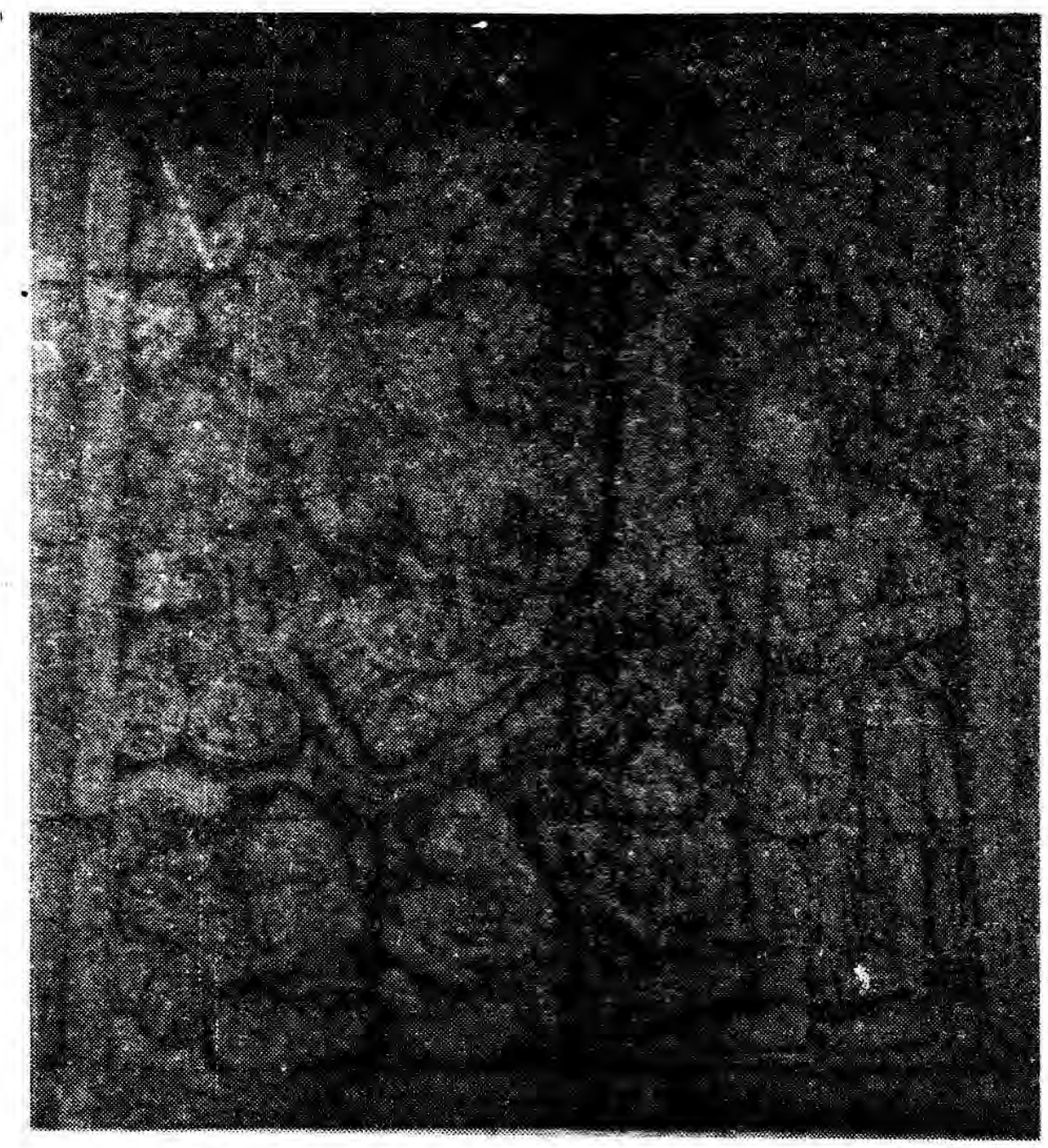

2. Panataran relief. Rama 


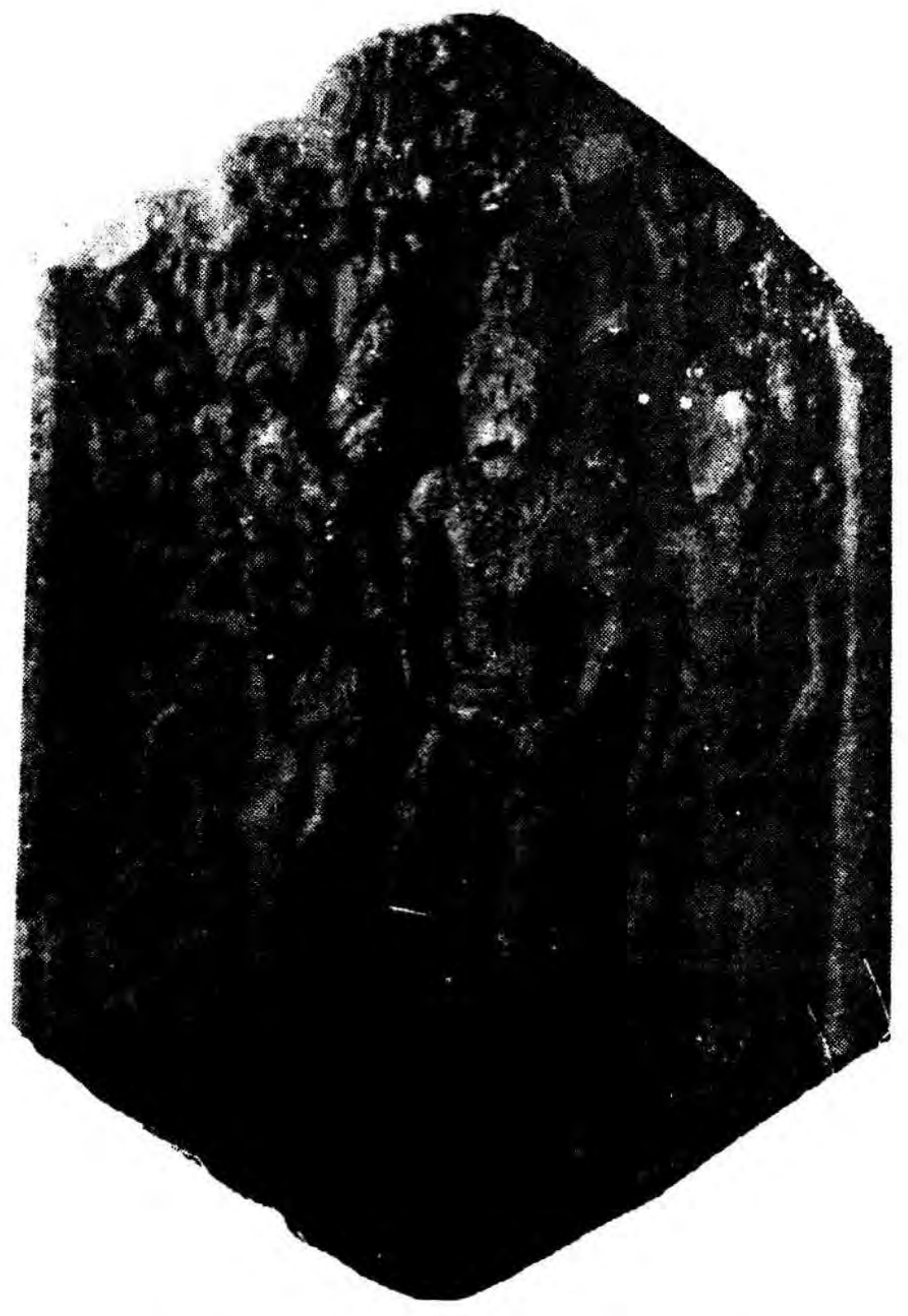

3. Mantingan relief. Rama. 


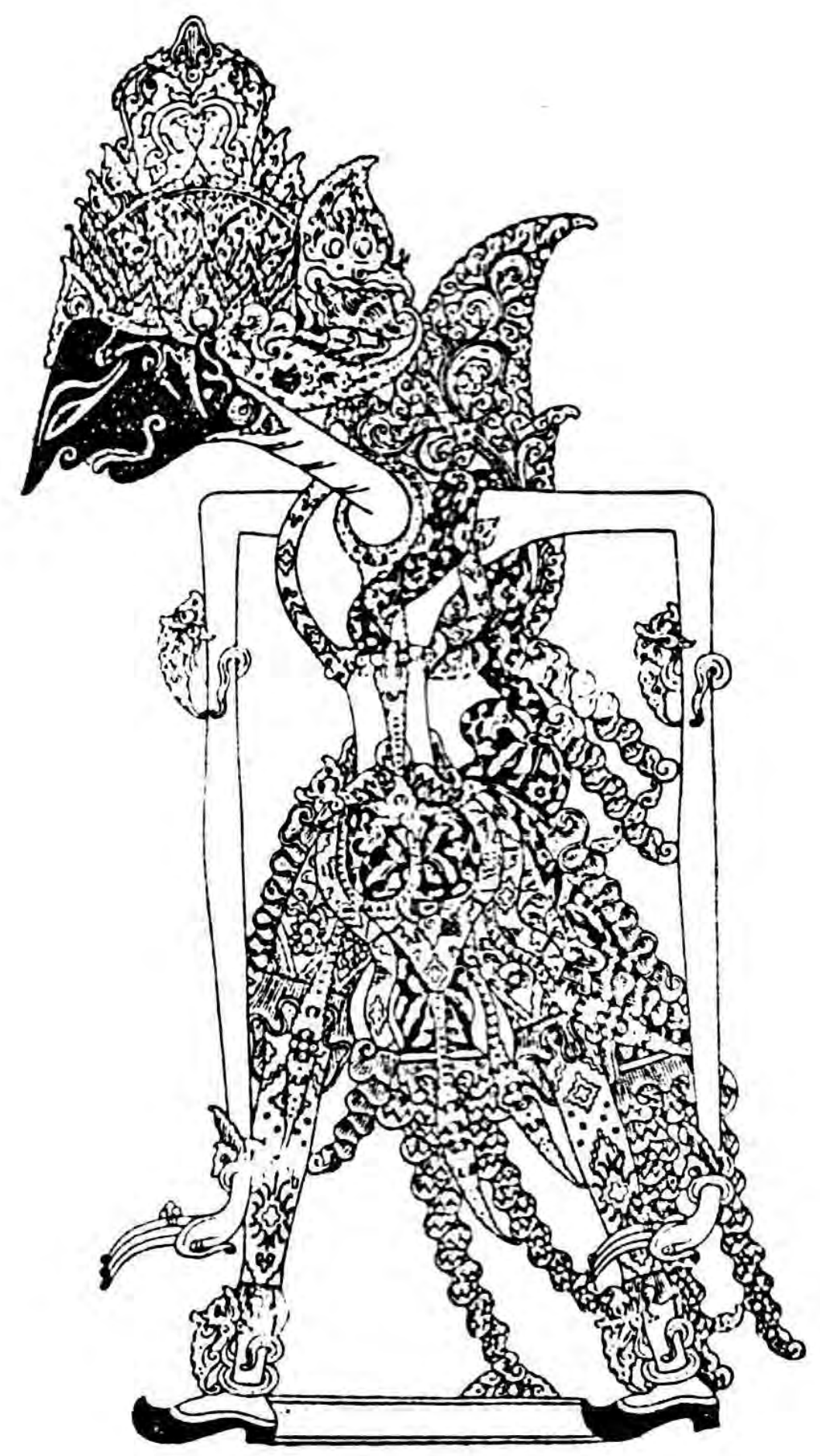

4. Wayang puppet. Rama type $A$ (J. Kats. 1923: p. 230) 


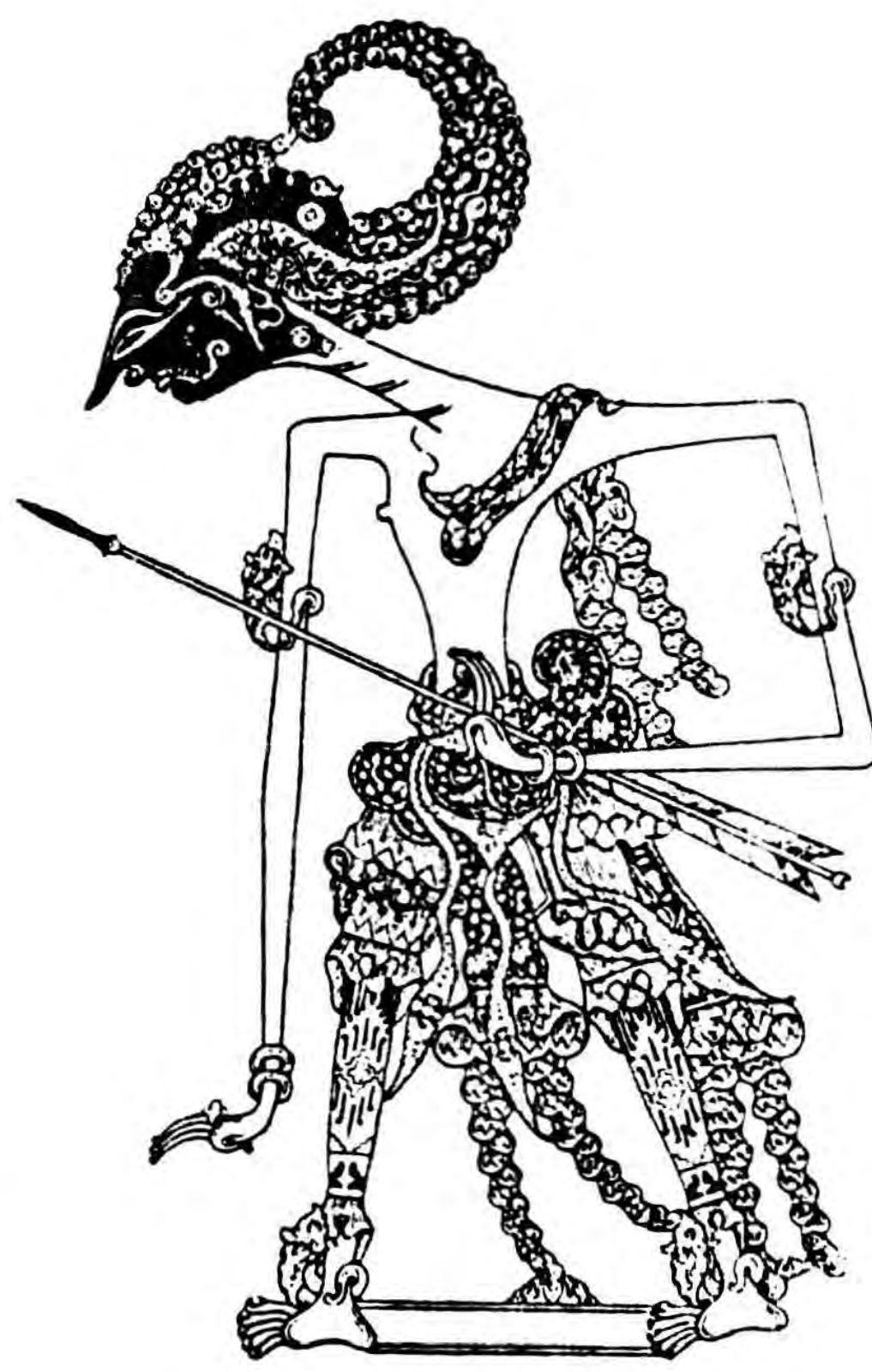

5. Wayang puppet. Rama type $B$ (J. Kats. 1923: p. 212) 